\title{
Therapeutic uses of security: mapping forensic mental health services by stratifying risk
}

\author{
H. G. Kennedy
}

The syllabus for higher training in forensic psychiatry requires knowledge of the therapeutic uses of security, although there are no references to this in standard texts. Similarly, the process of mapping a mental health service is an essential first step in planning, audit and needs assessment. All mental health services, not just forensic services, are organised to stratify patients according to the risk they present so that they can be cared for in an environment that is safe but imposes the minimum necessary restrictions and intrusions. Forensic mental health services differ from other mental health services mainly by including subsystems which are at higher levels of security than those necessary in local services. Although they have a general orientation towards risk awareness and risk management, they remain integral parts of the mental health services for the populations they serve.

A history of the evolution of secure psychiatric services in the UK is given in the Butler report (Home Office \& Department of Health and Social Services, 1975). An international perspective can be found in Bluglass \& Bowden (1990). Definitions of secure services often rely on descriptions of services currently available, so that a given level of security is defined, by default, as that which falls between adjacent levels. Attempts are being made to define and validate the characteristics of groups of patients that may require elements of security as part of their care (Cohen \& Eastman, 2000), but this is difficult to achieve without relying on current practice for validation in a circular way. Secure settings are found in general and forensic mental health services and in the independent sector. There is a wide variation between services, e.g. in the level of physical security in medium secure units. Published needs assessments all illustrate a considerable degree of inappropriate placement within the overall system, partly reflecting delays in transfer and partly due to the varied pattern of provision across the country.

\section{Principles}

The Butler (Home Office \& Department of Health and Social Services, 1975) and Reed (1992) reports set out principles which are widely acknowledged as the basis for secure psychiatric services. More recently, the King's Fund report, London's Mental Health (Johnson et al, 1997), contains much to guide the mapping of mental health services in urban settings. A current approach to mapping any mental health service would emphasise the importance of a whole-system approach, with cooperation between agencies ensuring that service boundaries do not operate as barriers to the movement of individuals across levels of security, according to their needs.

Continuity of responsibility is as important as continuity of care and it ensures the safe transition of individuals between levels of security. Services can best be organised so that multi-disciplinary teams have responsibilities across adjacent levels of security, within a given facility or across services.

Facilities should provide individuals with an environment that is least restrictive, safest, homely and local. Decreasing reliance on distant providers should therefore be a priority for service development. The sharing of information between agencies

Harry Kennedy is consultant forensic psychiatrist at the Central Mental Hospital, Dundrum (Dublin 14, Ireland). His research interests include the epidemiology of homicide and suicide as related to deprivation and urbanisation, the organisation of forensic mental health services and the psychopathology of anger. 
should take account of both public safety and confidentiality, and should occur to the extent that those with responsibility for treatment need to know.

\section{Definitions}

Any mental health service, be it a special hospital or a community mental health team (CMHT), an old age service or a child psychiatry service, can be described according to its environmental, relational and procedural security characteristics (Box 1).

\section{Environmental security}

Measures for environmental or physical security are often installed, at high capital cost, to help manage public confidence. Table 1 summarises the constructional and hardware characteristics of high, medium and low secure units. A useful guide to best practice in the design and construction of medium secure

Box 1 Definitions of security (after Kinsley, 1998)

Environmental security

Design and maintenance of estate and fittings

The staff necessary to operate them

Relational security

Quantitative: the staff-to-patient ratio and amount of time spent in face-to-face contact

Qualitative: the balance between intrusiveness and openness; trust between patients and professionals

Procedural security

Policies and practices for controlling risk:

- At the patient level: systems and routines for the control and checking of patients' movements and communication generally

- At the systems level: arrangements for professional governance, risk management, crisis and contingency planning, formalised reviews and transfer of responsibilities

Specialist management arrangements

Lines of responsibility:

- Management resources, lines of reporting and responsibility

- Weekly monitoring and benchmarking of admission, transfer and discharge criteria

- Processes for ensuring compliance with legal and policy requirements

- Maintenance of inter-agency relationships and boundaries units is given in a publication by the National Health Service Estates Agency (1999). The Royal College of Psychiatrists (1998) has published a set of recommendations regarding the quality and design of new acute adult mental health in-patient units. These emphasise the importance of ensuring that there is a high standard of maintenance and decoration as a tangible sign of respect for the patients detained within. There are theoretical grounds for believing that swift action on repairs and maintenance prevents a general increase in vandalism (Wilson \& Kelling, 1982). Guides to standards for the physical environment were set out by the Special Hospitals Service Authority (Hinton, 1998). These have been revised with reference only to high-security units (Tilt, 2001).

It is notable that, in general, long-term units require larger grounds within the secure perimeter and perhaps $30 \%$ more floor space per patient.

\section{Relational security}

Relational security is nearer to quality of care and is closely linked to resources or recurring (revenue) cost.

Medium-term units typically have high staffing ratios and intensive treatment programmes for all patients (Table 2). There is a tendency for the larger units to have lower overall nurse-to-patient ratios, since their pre-discharge wards typically operate at lower levels of relational security. Larger units tend to have higher ratios of psychologists to patients, suggesting better organised specialist treatment programmes. There has been little research on these variations (Royal College of Psychiatrists, 1975). For long-stay units there are usually lower levels of relational security (lower staff-to-patient ratios), although some units compensate for this with higher levels of environmental and procedural security.

Relational security is not solely dependent on staffto-patient ratios. James et al (1990) report more violent incidents on a locked psychiatric intensive-care ward when nursing shifts included higher proportions of agency or bank staff. This suggests that therapeutic rapport is important, even in high-turnover wards where patients are very disturbed. Table 3 shows features distinguishing different types of unit.

\section{Procedural security}

Procedural security is increasingly the subject of governmental directive, mental health legislation and judicial review at national or European level. It includes policies and practices relating to patients which control access, communication, personal finances and possessions. Procedural security within a service or an institution also covers policies and practices in relation to quality and governance, 


\begin{tabular}{|c|c|c|c|c|c|}
\hline Security feature & $\begin{array}{l}\text { Forensic } \\
\text { community } \\
\text { services }\end{array}$ & $\begin{array}{l}\text { Open wards } \\
\text { and 24-hour } \\
\text { nursed care }\end{array}$ & Low secure & Medium secure & High secure \\
\hline Perimeter & $\mathrm{N} / \mathrm{A}$ & $\mathrm{N} / \mathrm{A}$ & $\begin{array}{l}\text { Fenced garden } \\
\text { area }\end{array}$ & $\begin{array}{l}\text { Retardant, } \\
\text { e.g. 3-m close- } \\
\text { mesh fence }\end{array}$ & $\begin{array}{l}\text { Escape-proof, } \\
\text { e.g. 6-m wall }\end{array}$ \\
\hline Buildings & $\mathrm{N} / \mathrm{A}$ & $\begin{array}{l}\text { Controlled } \\
\text { access to } \\
\text { building }\end{array}$ & $\begin{array}{l}\text { Doors and } \\
\text { windows locked }\end{array}$ & $\begin{array}{l}\text { Escape-proof } \\
\text { building }\end{array}$ & $\begin{array}{l}\text { Controlled } \\
\text { access } \\
\text { to entire site }\end{array}$ \\
\hline $\begin{array}{l}\text { Observation } \\
\text { systems }\end{array}$ & $\mathrm{N} / \mathrm{A}$ & $\begin{array}{l}\text { Some patient } \\
\text { areas } \\
\text { unobserved }\end{array}$ & $\begin{array}{l}\text { Designed to allow } \\
\text { staff observation } \\
\text { and interaction at all } \\
\text { times if necessary }\end{array}$ & $\begin{array}{l}\text { CCTV in some } \\
\text { areas }\end{array}$ & $\begin{array}{l}\text { CCTV and } \\
\text { floodlights in } \\
\text { grounds }\end{array}$ \\
\hline $\begin{array}{l}\text { Alarm } \\
\text { systems }\end{array}$ & $\begin{array}{l}\text { Mobile } \\
\text { phones }\end{array}$ & $\begin{array}{l}\text { Wall-mounted } \\
\text { in some areas }\end{array}$ & $\begin{array}{l}\text { Staff personal } \\
\text { alarms } \\
\text { Wall-mounted } \\
\text { in all areas }\end{array}$ & $\begin{array}{l}\text { Increasing } \\
\text { complexity, } \\
\text { e.g. staff tracking } \\
\text { via electronic keys }\end{array}$ & $\begin{array}{l}\text { All previously } \\
\text { listed }\end{array}$ \\
\hline
\end{tabular}

including information management, legal obligations, audit, research and human resources. It is summarised in Table 4 by patient-focused policies and practices. Box 1 shows additional management issues.

Specific aspects of procedural security include the management of violent incidents and acute excited states, including de-escalation, breakaway techniques, control and restraint, seclusion and forced medication (Royal College of Psychiatrists, 1995). There has been little systematic study in this area although, from time to time, it receives intense media interest.

Monahan (1993) has outlined a scheme for risk containment to reduce the incidence of violence and establish a standard for best practice. Risk containment includes risk assessment, risk management, documentation, policy and damage control. Powell (1998) describes both the broad and the specific problems dealt with as policy issues in institutions (e.g. the definition of seclusion) and also as management issues around changing institutional culture. Tilt (2000) has recently criticised the prevailing norms for procedural and physical security in high-security hospitals. The Tilt team recommended enhanced physical security to match category B prisons in the UK, including a greater emphasis on procedural security, with increased numbers of dedicated security staff, greater security training and more security audits. The extent to which this will permeate all secure hospital services remains to be seen.

\section{Mapping systems}

For mapping purposes, any mental health service can be described as a system made up of subsystems.

Table 2 Relational security (quantitative): mean staff-to-patient ratios for seven National Health Service medium secure units in London

$\begin{array}{lccc} & \text { Mean } & \text { Minimum } & \text { Maximum } \\ \text { Beds (7 medium secure units) } & 51.7 & 23 & 91 \\ \text { Staff per bed } & 1.85 & 1.65 & 2.3 \\ \quad \text { Nurses } & & & 3.6 \\ \text { Beds per staff member } & 6.25 & 0.0 & 4.8 \\ \quad \text { Occupational therapists } & 9.1 & 16.7 & 5.9 \\ \quad \text { Psychologists } & 11.1 & 25.0 & 7.7 \\ \quad \text { Social workers } & 9.1 & 14.3 & 10.0 \\ \quad \text { Consultants } & 16.7 & 0.0 & 10.0 \\ \quad \text { Specialist registrars } & 16.7 & 25.0 & \end{array}$


Forensic services are, therefore, always a subsystem of the mental health service for a given region. Table 5 sets out a matrix which stratifies units (subsystems) according to security, length of stay and population served. This attempts to describe a whole system by including open and community units at local and regional levels. The interdependence of these services can be seen in the apparent inverse relationship between the availability of local low secure beds and demand for regional medium secure beds (O'Grady, 1990; Coid et al, 2001a). Every system, and every subsystem within it, can be mapped according to its structures, processes and outcomes (Box 2). This is also a useful approach when drafting operational policies.

Certain groups of patients may require additional specialised services organised at regional or supraregional level, e.g. services for women, adolescents or those with learning disabilities.

\section{Risk stratification maps}

Scott (1977) described dangerousness as a dangerous concept and defined it as the product of probability (or immediacy) of risk and the gravity of the

\section{Box 2 Mapping models}

\section{Structures}

Stratified according to the risk currently presented by the patient; length of stay; pathways through care; specialised or generic

Processes

Ascertainment (e.g. screening services or referral routes); assessment; treatment; rehabilitation; continuing care (or transfer or discharge) (see also procedural security)

\section{Outcomes}

Hard outcomes:

- suicide and unnatural death

- homicide and violence to others

- (time to) full remission of symptoms

- period relapse-free, and continued contact with services when outside hospital

Soft outcomes:

- patient's and relatives' satisfaction

- public confidence

- economic (cost)-effectiveness measures

risk. Stratification of patients, by allocating them to appropriate levels of security according to their

Table 3 Relational security guidelines (quantitative)

\begin{tabular}{|c|c|c|c|c|c|}
\hline & $\begin{array}{l}\text { Forensic } \\
\text { community } \\
\text { services }\end{array}$ & $\begin{array}{l}\text { Open wards and } \\
\text { 24-hour nursed } \\
\text { care }\end{array}$ & Low secure & Medium secure & High secure \\
\hline $\begin{array}{l}\text { Staff-to- } \\
\text { patient } \\
\text { ratios }\end{array}$ & $\begin{array}{l}\text { Two key } \\
\text { workers } \\
\text { Higher ratios } \\
\text { for high-risk } \\
\text { patients }\end{array}$ & $\begin{array}{l}\text { Variable } \\
\text { according to } \\
\text { risk } \\
\text { Higher in acute } \\
\text { units }\end{array}$ & $\begin{array}{l}\text { Lower than } \\
\text { in Table } 2\end{array}$ & $\begin{array}{l}\text { As in Table } 2 \\
\text { some reductions } \\
\text { in long-term } \\
\text { units }\end{array}$ & As in Table 2 \\
\hline $\begin{array}{l}\text { Team reviews } \\
\text { of risk and } \\
\text { treatment } \\
\text { plans }\end{array}$ & $\begin{array}{l}\text { 2- to 12-week } \\
\text { intervals } \\
\text { Higher for } \\
\text { recent } \\
\text { discharges }\end{array}$ & $\begin{array}{l}2 \text { - to } 12 \text {-week } \\
\text { intervals } \\
\text { according to } \\
\text { time since } \\
\text { admission }\end{array}$ & $\begin{array}{l}\text { 1- to } 4 \text {-weekly } \\
\text { for acute units } \\
12 \text {-weekly for } \\
\text { long-term units }\end{array}$ & $\begin{array}{l}4 \text {-weekly up to } \\
18 \text { months } \\
\text { 6-weekly after } \\
18 \text { months }\end{array}$ & $\begin{array}{l}\text { As for } \\
\text { medium } \\
\text { secure }\end{array}$ \\
\hline $\begin{array}{l}\text { Specialist } \\
\text { treatment } \\
\text { skills }\end{array}$ & $\begin{array}{l}\text { Family work } \\
\text { Social } \\
\text { re-integration }\end{array}$ & $\begin{array}{l}\text { Illness } \\
\text { awareness } \\
\text { Addictions } \\
\text { work }\end{array}$ & $\begin{array}{l}\text { Victim } \\
\text { awareness } \\
\text { Anger } \\
\text { management }\end{array}$ & $\begin{array}{l}\text { Specialist } \\
\text { cognitive and } \\
\text { psychodynamic }\end{array}$ & $\begin{array}{l}\text { All previously } \\
\text { listed }\end{array}$ \\
\hline $\begin{array}{l}\text { Inter-agency } \\
\text { work }\end{array}$ & $\begin{array}{l}\text { Local CMHT } \\
\text { liaison } \\
\text { Benefits } \\
\text { agencies } \\
\text { Primary care }\end{array}$ & $\begin{array}{l}\text { Housing } \\
\text { Social services } \\
\text { Home Office/ } \\
\text { Department } \\
\text { of Justice }\end{array}$ & $\begin{array}{l}\text { Courts } \\
\text { Prisons } \\
\text { Probation }\end{array}$ & $\begin{array}{l}\text { Host Regional } \\
\text { Health } \\
\text { Authorities }\end{array}$ & $\begin{array}{l}\text { National } \\
\text { agencies } \\
\text { and all } \\
\text { previously } \\
\text { listed }\end{array}$ \\
\hline $\begin{array}{l}\text { Recreational } \\
\text { programmes }\end{array}$ & $\begin{array}{l}\text { Community } \\
\text { based }\end{array}$ & $\begin{array}{l}\text { Sheltered } \\
\text { workshops }\end{array}$ & $\begin{array}{l}\text { Sports and } \\
\text { diversion }\end{array}$ & $\begin{array}{l}\text { Education } \\
\text { Occupational } \\
\text { rehabilitation }\end{array}$ & $\begin{array}{l}\text { All } \\
\text { previously } \\
\text { listed }\end{array}$ \\
\hline
\end{tabular}


Table 4 Procedural security guidelines

Forensic Open wards community and 24-hour services nursed care

Visits No restrictions

Some visitors excluded

Communication

No restrictions

No restrictions

N/A

Access to

No No money restrictions
Low secure

Ex-patients often excluded Parcels, bags, etc. searched on entry

Parcels opened
Searching for weapons and intoxicants in specific cases

Parcels and purchases searched on return from leave restrictions
Patient trades not allowed
Medium secure High secure

Visits only from Visits by prior identified list written Child visits specially arrangement controlled Visitors require Visits observed identification Pat-down searches

Communication to specific individuals may be limited or prevented

Letters and telephone calls in and out monitored Legal communications not monitored

Regular searches Pat-down searches of room and property Regular searches of site

Access to cash limited

All financial affairs monitored dangerousness, is essential for the safe and effective deployment of limited resources. The most important element of security is the staffing ratio, which is also the most expensive resource. Appropriate levels of staffing maintain a safe environment. This enables all other elements of treatment to proceed and is itself a key feature of any therapeutic milieu. Patients are acutely aware of the day-to-day safety of their environment. Dangerous patients can be managed economically in extremis by confining them to their rooms, but no therapeutic progress will then be achieved. Admission units typically have higher staffing levels than rehabilitation or long-term care units. Similarly, frequency of contact with community care services is usually greater in the months immediately after discharge than in later months.

Table 5 Mapping whole systems: security, length of stay and population served

\begin{tabular}{|c|c|c|c|c|c|}
\hline & Community & Open hospital & Low secure & Medium secure & High secure \\
\hline $\begin{array}{l}\text { Short-term, } \\
\text { under } \\
6 \text { months }\end{array}$ & $\begin{array}{l}\text { ICM, ACT; crisis } \\
\text { house; police station, } \\
\text { court and prison } \\
\text { liaison and diversion } \\
\text { teams }\end{array}$ & $\begin{array}{l}\text { Generic/local } \\
\text { mental health } \\
\text { unit }\end{array}$ & $\begin{array}{l}\text { Locked generic/ } \\
\text { local PICU, FICU }\end{array}$ & $\begin{array}{l}\text { Regional } \\
\text { medium secure } \\
\text { unit }\end{array}$ & $\begin{array}{l}\text { Medium } \\
\text { secure unit } \\
\text { admission } \\
\text { wards, special } \\
\text { hospital }\end{array}$ \\
\hline $\begin{array}{l}\text { Medium-term, } \\
6 \text { months } \\
\text { to } 3 \text { years }\end{array}$ & $\begin{array}{l}\text { ICM, ACT, CMHT, } \\
\text { day hospital, hostel, } \\
\text { forensic community } \\
\text { teams (integrative } \\
\text { model) }\end{array}$ & $\begin{array}{l}\text { Rehabilitation } \\
\text { wards }\end{array}$ & $\begin{array}{l}\text { FICU, long-term } \\
\text { low secure unit }\end{array}$ & $\begin{array}{l}\text { Medium-term } \\
\text { medium secure } \\
\text { unit }\end{array}$ & Special hospital \\
\hline Long-term & $\begin{array}{l}\text { Core and cluster, } \\
\text { day centre, } \\
\text { sheltered workshop; } \\
\text { forensic community } \\
\text { teams (parallel) }\end{array}$ & $\begin{array}{l}\text { 24-hour nursed } \\
\text { care, general or } \\
\text { forensic }\end{array}$ & $\begin{array}{l}\text { Long-term } \\
\text { low secure unit }\end{array}$ & $\begin{array}{l}\text { Long-term } \\
\text { medium secure } \\
\text { unit }\end{array}$ & Special hospital \\
\hline $\begin{array}{l}\text { Population } \\
\text { served }\end{array}$ & $\begin{array}{l}\text { Local or district, } \\
30000-50000\end{array}$ & $\begin{array}{l}\text { District, } \\
200 \text { 000-400 } 000\end{array}$ & $\begin{array}{l}\text { District or regional } \\
1.5-3.5 \text { million }\end{array}$ & $\begin{array}{l}\text { Regional, } \\
1.5-3.5 \text { million }\end{array}$ & $\begin{array}{l}\text { Regional/ } \\
\text { national }\end{array}$ \\
\hline
\end{tabular}

ICM, intensive case management; ACT, assertive community treatment; CMHT, community mental health team; PICU, psychiatric intensive care unit; FICU, forensic intensive care unit. 
Research has recently shown that fewer patients are admitted on civil sections to London's forensic services, and also that London has a higher proportion of restriction-order patients than do other regions of England (Coid et al, 2001b). At the same time, the numbers admitted to special hospitals are falling year on year (Jamieson et al, 2000). It appears that admission thresholds are drifting upwards in a responsive but unplanned manner, determined by availability of resources rather than any more objective criteria. By allowing the threshold for admission to secure services to become a flexible function of demand and available resources, an equitable service for all dangerous patients can be provided for a given region. However, thresholds can then become inconsistent between regions and they are disconnected from any guideline level of clinical risk or outcome measure.

Patients should be detained at no greater level of security than is necessary. This principle can be seen in the organisation of secure psychiatric services according to stratified risk. A secure environment must, within the limits of mental health legislation, restrict freedom of movement, access and communication, and it tends to intrude into areas that are normally kept private. Imposing a treatment plan on a patient who is incompetent to give or withhold consent can be justified ethically if, by so doing, the patient can receive services which restore him or her to mental health and, with it, to autonomy, responsibility and increased freedom (Eastman, 1997). The current level of detention should therefore be regularly reviewed under a clearly recorded risk assessment and clinical risk management plan (a treatment plan). This should be explicit about the treatments required and the markers for progress towards transfer to a lower level of security.

\section{Risk assessment in a stratified systems}

From a clinical point of view, all decisions to admit, transfer to a lower level of security or discharge can be reduced to a single triage process in which the patient is matched to the appropriate level of available security. In the real world, risk assessment is never separate from risk management; there are only varieties of triage decisions. From a statistical point of view, having a high threshold for admission enables subsequent clinical risk assessment and risk management to be more accurate, with fewer false positives, both by increasing the average risk within the selected patient group and by reducing the amount of variation in the patient population.

Recorded crimes of violence are much more common than homicide, by a factor of at least 200 for the general population (Kennedy et al, 1999), and the real rate of violence in the community is even greater. Violence should, therefore, be easier to predict than homicide or suicide, with extra services being targeted at about $11 \%$ of patients with severe mental illness (Kennedy, 2001).

It is wrong to assume that all groups of psychiatric patients are actually at the average level of risk for such patients on a national basis. The prevailing rate of violence in the community by patients with schizophrenia is already modified by risk stratification in mental health services. Snowden et al (1999) points out that three-quarters of patients under a restriction order are in hospital at any one time. Even for populations of patients defined by local sectors, most of those at the highest risk will be in hospital owing to acute relapses. For inner-city populations where violent crime is more common (Kennedy et al, 1999), a higher proportion will be in secure forensic units (Glover et al, 1999). In community forensic populations, the average risk of grade 1 or grade 2 violence (Table 6) is higher than for patients in general psychiatric community services. For a test with a given sensitivity, the predictive value of the instrument improves as the prevalence of the disorder in the test population increases (Goldstein \& Simpson, 1995). Stratification of risk, therefore, favours more accurate prediction of risk of serious harm in both forensic and general patient populations, by raising the average risk of serious harm in the forensic population while at the same time reducing the average risk of serious harm in the general psychiatric population.

Table 6 Violence at presentation as a guide to security needed at the time of admission (NB: this should never be taken in isolation from the other factors listed in Table 8)

\begin{tabular}{|c|c|}
\hline $\begin{array}{l}\text { Graveness } \\
\text { of violence }\end{array}$ & Behaviour \\
\hline $\begin{array}{l}\text { High } \\
\text { (grade 1) }\end{array}$ & $\begin{array}{l}\text { Homicide } \\
\text { Stabbing penetrates body cavity } \\
\text { Fractures skull } \\
\text { Strangulation } \\
\text { Serial penetrative sexual assaults } \\
\text { Kidnap, torture, poisoning }\end{array}$ \\
\hline $\begin{array}{l}\text { Medium } \\
\text { (grade 2) }\end{array}$ & $\begin{array}{l}\text { Use of weapons to injure } \\
\text { Arson } \\
\text { Causes concussion or fractures } \\
\text { long bones } \\
\text { Sexual assaults } \\
\text { Stalking with threats to kill }\end{array}$ \\
\hline $\begin{array}{l}\text { Low } \\
\text { (grade 3) }\end{array}$ & $\begin{array}{l}\text { Repetitive assaults causing bruising } \\
\text { Self-harm or attempted suicide that } \\
\text { cannot be prevented by two-to-one } \\
\text { nursing in open conditions }\end{array}$ \\
\hline
\end{tabular}


Risk is also stratified in time. The risk of suicide is greatest in the year after discharge from hospital, and is of the order of 1 per 100 patient-years (Geddes et al,1997). The risk of violence is also highest in the months immediately after discharge from hospital (Steadman et al, 1998). This natural stratification of risk should enable more accurate risk assessments to be made for the period immediately after leaving hospital because of the higher average risk during that period. More intensive contact with mental health services (relational and procedural security) might be expected to manage the risk within the bounds of what is possible or predictable. The importance of early review after discharge from hospital has been emphasised (Appleby, 1997; Royal College of Psychiatrists, 2000), as $40 \%$ of postdischarge suicides occur before the first follow-up appointment.

Just as it is wrong to assume that all patient populations are at the national average for a given risk, it is wrong to assume that the average risk in any patient group is made up from a wide range of risk. Within forensic services, the aim is to stratify patients so as to narrow the range of individual risk within each group. This allows the levels of therapeutic security to be matched to the current need, determining the pace of progress through treatment settings, from admission to rehabilitation to community placement. Forensic patients are selected for discharge (see Table 7) when they are stable, predictable and willing to tolerate a degree of intrusion and control by clinicians in the community. Those in the community should also be stratified according to risk. This stratification across treated groups tends to increase variation and improves the reliability of predictive measures (Shrout, 1995). For all psychiatric facilities, length of stay may be a function of the match between need and resources and thiscan appear to influence risk management. For example, a disproportionate number of suicides within 3 months of hospital discharge were found to have had final admissions lasting 7 days or less (Appleby, 1997). Geddes et al (1997) have drawn attention to the apparent link between a rise in early post-discharge suicides and the fall in the number of hospital beds.

An important caveat regarding risk prediction concerns the assumption that all local populations from which patients are drawn are at the same average risk as the total population. This is not true. In inner-city boroughs, the population risk of homicide, suicide or recorded crimes of violence increases exponentially with population density or deprivation (Kennedy et al, 1999). This variable background of environmental risk probably makes the risk of adverse outcomes such as violence, homicide or suicide worse for a given patient and probably limits the clinician's capacity to make anything more than short-term predictions when the environmental risk is high.

This long-standing structural risk management at the systems level may have been lost in modern sectorised CMHTs and small generic in-patient units. If general psychiatrists manage mixed populations of patients, most of whom are at a 1 in 10000 per year risk of committing homicide, as

\section{Table 7 Signs of diminished need for security}

\begin{tabular}{|c|c|c|c|}
\hline Move & High to medium secure & Medium to low secure & To community or open placements \\
\hline Stability & $\begin{array}{l}\text { Two years' stability } \\
\text { Relapses may be abrupt, } \\
\text { over days }\end{array}$ & $\begin{array}{l}\text { One year's stability } \\
\text { Relapses may be abrupt, } \\
\text { over days }\end{array}$ & $\begin{array}{l}\text { Relapses occur over weeks and are } \\
\text { predictable }\end{array}$ \\
\hline Insight & $\begin{array}{l}\text { Accepts legal obligations } \\
\text { to take treatment as a } \\
\text { minimum }\end{array}$ & $\begin{array}{l}\text { Accepts treatment and } \\
\text { legal obligations } \\
\text { Is encouraged to do so by } \\
\text { closest friends or family }\end{array}$ & $\begin{array}{l}\text { Realistic appraisal of risk of relapse } \\
\text { Practical approach to relapse } \\
\text { prevention } \\
\text { Family and friends, if involved, are } \\
\text { aware and supportive }\end{array}$ \\
\hline Rapport & $\begin{array}{l}\text { Tolerates daily intrusions } \\
\text { and constrictions of } \\
\text { hospital life } \\
\text { Participates in treatment } \\
\text { and occupational } \\
\text { programmes }\end{array}$ & $\begin{array}{l}\text { Capable of openness and } \\
\text { trust with members of } \\
\text { multi-disciplinary team } \\
\text { Capable of limited } \\
\text { exploration of current } \\
\text { mental state as related } \\
\text { to risk }\end{array}$ & $\begin{array}{l}\text { Open and trusting with all members } \\
\text { of multi-disciplinary team } \\
\text { Capable of communicating matters } \\
\text { relevant to risk } \\
\text { Tolerates intrusion and restricted } \\
\text { autonomy of treatment plan } \\
\text { Not excessively dependent on others }\end{array}$ \\
\hline Leave & $\begin{array}{l}\text { None necessary } \\
\text { Visits prior to trial leave } \\
\text { are usual }\end{array}$ & $\begin{array}{l}\text { Can use escorted leave } \\
\text { in hospital grounds most } \\
\text { of the time and escorted } \\
\text { community leave } \\
\text { sometimes }\end{array}$ & $\begin{array}{l}\text { Capable of using unescorted leave } \\
\text { in the community for over } 6 \text { months }\end{array}$ \\
\hline
\end{tabular}


Szmukler (2000) suggests, they may be unaware that a few of their patients are at a much higher risk. Even with little regard for risk management, most psychiatrists responsible for catchment populations of 30000 to 50000 would seldom experience adverse outcomes and they may be unaware of the risks they run in some cases. It follows that the mixing of all patients from a catchment area in small-sector generic services is bad risk management at the systems level. The commissioning of services at local or primary care level is similarly flawed. If plans are made for a population that is too small, the need to stratify some patients to specialised care for the higher, less common levels of risk will rarely arise and will never be anticipated. This can make risk assessment less accurate and risk management too diffused. These forms of functional risk-blindness are likely to be particularly hazardous in high-risk inner-city boroughs. A greater emphasis is needed on systems defences to harness human variability and to avert or mitigate the effects of errors and adverse outcomes (Reason, 2000).

\section{Patient characteristics}

All patients in secure psychiatric services are likely to share certain characteristics. There is an inherent problem of circularity in seeking to define the patient characteristics appropriate for a type of secure unit or define the level of security by describing those currently in such units, when to operate according to a strictly theoretical model creates a system that can never be tested by experiment. Audit cycles for whole clinical services to a defined population (whole systems) offer the possibility of the evolution of pragmatic criteria over time.

Gunn \& Robertson (1976) published a system for profiling patients according to their criminal history. Shaw et al (1994) published a description of the clinical characteristics of patients in high-security situations and related these to placement needs. Many similar studies have followed. Coid \& Kahtan (2000) have published a 4-point scale for describing patients according to severity of offence and levels of security on admission. The scale takes into account the patient's status within the criminal justice system, specifically for England and Wales. Cohen and Eastman (2000) offer theoretical headings under which working admission criteria can be developed for research purposes.

Tables 6 and 8 summarise relevant guidelines for admission. They are derived from the panel rating process for 122 patients detained in high and medium secure units described by Pierzchniak et al
(1999). It is not proposed here that Grade 1 violence alone automatically equates to need for high security, since other factors are also relevant. As outlined above, there is likely to be considerable variation between institutions and catchment areas which has more to do with local morbidity and resource allocation than any theoretical construct.

Guidelines for moving a patient to lower levels of security and eventually to community care are much more difficult to operationalise. It cannot be presumed that all patients will automatically progress within defined periods of time. Nor does the time spent at a given level of security without gross disturbance automatically indicate that the patient could be safely managed in a less secure place. Reasonable clinical criteria include evidence that dispositional, situational and mental illness factors relevant to the risk of violent behaviour are understood and are reduced by treatment, and that changes indicating risk could be monitored and managed at a lower level of security. This requires evidence that the patient is capable of engaging honestly in a positive therapeutic rapport with clinicians over sustained periods, that they tolerate intrusive clinicians and are open with them, that they accept some loss of autonomy in relation to treatment and the care plan generally, and that the patient's friends and family can be fully engaged with the clinical team in future monitoring and treatment. Local and victim issues must also be taken into account and they can result in longer detention at higher levels of security than might strictly be necessary to manage risk. Table 7 summarises these considerations, again based on the panel ratings and discussions described in Pierzchniak et al (1999).

\section{Continuity of responsibility}

Moving a patient to a new placement or new clinical team is, in itself, likely to increase risk. Recommendations for taking such therapeutic risks are more credible if they are made by the clinicians who will take responsibility for the risk. Clinicians are sensitive to this and the decision to move the patient is more likely to be implemented quickly and successfully if the recommendation is made under these conditions. Failure to observe this ethical continuity often gives rise to conflict and undermines therapeutic relationships (e.g. $\mathrm{R} v$. Mental Health Review Tribunal and Others ex parte Hall, 1999).

It is better to stagger the change in placement and clinicians. For this to happen, clinical teams should have responsibility for places at more than one level of security. The new team of clinicians can then establish rapport and trust with the patient before a further move is made down the ladder of security. 


\begin{tabular}{|c|c|c|c|c|c|}
\hline $\begin{array}{l}\text { Admission } \\
\text { guidelines }\end{array}$ & $\begin{array}{l}\text { Forensic } \\
\text { community } \\
\text { services }\end{array}$ & $\begin{array}{l}\text { Open wards and } \\
\text { 24-hour nursed } \\
\text { care }\end{array}$ & Low secure & Medium secure & High secure \\
\hline $\begin{array}{l}\text { Violence } \\
\text { (grades } \\
\text { refer to } \\
\text { Table 6) }\end{array}$ & $\begin{array}{l}\text { No recent } \\
\text { violence }\end{array}$ & $\begin{array}{l}\text { Self-harm } \\
\text { Lesser degrees } \\
\text { of violence }\end{array}$ & $\begin{array}{l}\text { Grade } 3 \\
\text { Public order/ } \\
\text { nuisance } \\
\text { offending }\end{array}$ & Grade 2 & Grade 1 \\
\hline Immediacy & $\begin{array}{l}\text { Does not } \\
\text { need daily } \\
\text { monitoring }\end{array}$ & Confides in staff & $\begin{array}{l}\text { Acute illness } \\
\text { or crisis likely } \\
\text { to resolve in } \\
3-6 \text { months }\end{array}$ & $\begin{array}{l}\text { Relapses abrupt } \\
\text { Unpredictable }\end{array}$ & $\begin{array}{l}\text { Unpredictable } \\
\text { Inaccessible to } \\
\text { staff }\end{array}$ \\
\hline $\begin{array}{l}\text { Specialist } \\
\text { forensic } \\
\text { need }\end{array}$ & $\begin{array}{l}\text { Self-medicates } \\
\text { Previous } \\
\text { admissions to } \\
\text { medium or high } \\
\text { secure units } \\
\text { Reintegrating } \\
\text { with local services }\end{array}$ & $\begin{array}{l}\text { Cannot cooperate } \\
\text { with voluntary } \\
\text { treatment } \\
\text { Compliant when } \\
\text { formally detained }\end{array}$ & $\begin{array}{l}\text { Recall or crisis } \\
\text { of former } \\
\text { medium-/high- } \\
\text { security patient } \\
\text { Current mental } \\
\text { state associated } \\
\text { with violence }\end{array}$ & $\begin{array}{l}\text { Arson } \\
\text { Jealousy } \\
\text { Resentful } \\
\text { stalking } \\
\text { Exceeds low } \\
\text { secure capacity }\end{array}$ & $\begin{array}{l}\text { Sadistic } \\
\text { Paraphilias } \\
\text { associated with } \\
\text { violence } \\
\text { Exceeds medium } \\
\text { security }\end{array}$ \\
\hline Absconding & $\begin{array}{l}\text { Will not break off } \\
\text { contact }\end{array}$ & $\begin{array}{l}\text { If absconded, } \\
\text { would not present } \\
\text { an immediate } \\
\text { danger }\end{array}$ & $\begin{array}{l}\text { Impulsive } \\
\text { absconding }\end{array}$ & $\begin{array}{l}\text { Pre-sentence } \\
\text { serious charge } \\
\text { Other obvious } \\
\text { motivation to } \\
\text { abscond }\end{array}$ & $\begin{array}{l}\text { Can coordinate } \\
\text { outside help } \\
\text { Past absconding } \\
\text { from medium } \\
\text { or high security }\end{array}$ \\
\hline $\begin{array}{l}\text { Public } \\
\text { confidence } \\
\text { issues }\end{array}$ & $\begin{array}{l}\text { No local victim } \\
\text { sensitivities } \\
\text { No high-risk } \\
\text { relationships }\end{array}$ & No local notoriety & $\begin{array}{l}\text { Short-term } \\
\text { family } \\
\text { sensitivities }\end{array}$ & $\begin{array}{l}\text { Predictable } \\
\text { potential victims } \\
\text { Local notoriety }\end{array}$ & $\begin{array}{l}\text { National } \\
\text { notoriety }\end{array}$ \\
\hline
\end{tabular}

\section{Community forensic services}

The processes required by a comprehensive forensic mental health service include ascertainment and continuing care, which are the pathways into and out of secure forensic mental health services (Box 2).

\section{Ascertainment services}

Forensic mental health services typically provide psychiatric sessions to remand and dispersal prisons. The very large numbers of young men passing through the reception at remand prisons present a unique opportunity for health interventions in a high-risk group. Mental health needs are only a part of the problem, but the principal task should be to find those at increased risk of suicide and take appropriate action to reduce this risk (Birmingham et al, 1996), to identify those with severe mental illness and divert them to hospital and to provide rehabilitation services for those with addictions. These tasks are likely to overlap extensively. Since the greatest rise in suicides is among young men in inner cities and the very large remand population is predominantly drawn from these areas, it is likely that the remand prison reception centre is a common point of contact for many eventual suicides who will make no other contact with mental health services.

The growth of psychiatric diversion teams in magistrates' courts has been described in detail by James (1999). These teams can be shown to greatly reduce the time taken to divert mentally disordered offenders to hospital, particularly when there is close liaison or overlap with the remand prison psychiatrists (Pierzchniak et al, 1997). It can be argued that the numbers of patients recently discharged from mental health services re-presenting via court diversion schemes, expressed as a rate per 1000 discharges from local mental health services, could be used as a measure of the success or failure of community mental health policies and services (Purchase et al, 1996).

The extension of liaison and diversion services into police stations, typically by providing specialist community psychiatric nurses, can be shown to further enhance diversion of mentally disordered offenders to psychiatric services while also offering advice on services to those with addictions. These services supplement the work of the forensic medical 
examiner in the police station. The initiation of Mental Health Act assessments in police stations rather than in hospital-designated places of safety remains a problem. This probably arises, in part, from a lack of resources to staff such hospital units safely, and perhaps also from neglect of patients stigmatised by their presentation through the criminal justice system.

\section{Continuing care}

Gunn (1977) distinguished between integrated and parallel forensic follow-up services for those discharged from secure hospitals. More recently, Snowden et al (1999) have described a hybrid model, in which all those leaving medium or high secure beds are followed in the community by forensic community teams with low case-loads (high relational security) and an assertive community treatment approach. Once the patient has been settled and stable in a long-term community place for 6 to 12 months, a planned and phased transfer of care to the local mental health team is completed.

\section{Conclusions}

All mental health services maintain a safe and effective process of treatment and rehabilitation through the stratification of patients according to the risks they present. Awareness of the therapeutic importance of environmental, relational and procedural security is valuable in drafting safe treatment plans for patients and in the organisation and management of all mental health services. Relational security is by far the most important element in the maintenance of therapeutic progress of patients. Psychiatrists should be aware of the management, funding and policy issues relevant to maintaining this most essential part of the mental health services that we provide.

The definitions of levels of security given here are simplified guidelines only, but have been of benefit in planning and organising a catchment area service and in choosing appropriate placements for patients when these had to be out of area. The definitions and categories are also of some assistance in organising the operational policies for secure and other mental health units and broad services, particularly in relation to the resources required for risk management. The guidelines for transfer of patients from one level of security to another should also be taken to be flexible and for implementation only by experienced clinicians who can make an assessment of the individual patient. However, it is increasingly necessary to be able to communicate the form and content of such assessments as the basis of a clinical opinion when reporting to mental health tribunals, the Home Office and similar scrutinising authorities.

\section{References}

Appleby, L. (1997) National Confidential Inquiry into Suicide and Homicide by People with Mental illness: Progress Report 1997. London: Department of Health.

Birmingham, L., Mason, D. \& Grubin, D. (1996) Prevalence of mental disorder in remand prisoners: consecutive case study. BMJ, 313, 1521-1524.

Bluglass, R. \& Bowden, P. (eds) (1990) Principles and Practice of Forensic Psychiatry. London: Churchill Livingston.

Cohen, A. \& Eastman, N. (2000) Assessing Forensic Mental Health Need: Policy, Theory and Research. London: Gaskell

Coid, J. \& Kahtan, N. (2000) An instrument to measure the security needs of patients in medium security. Journal of Forensic Psychiatry, 11, 119-134.

-, - Cook, A., et al (2001a) Predicting admission rates to secure forensic psychiatry services. Psychological Medicine, $31,531-539$

-, - Gault, S., et al (2001b) Medium secure forensic psychiatry services: comparison of seven English health regions. British Journal of Psychiatry, 178, 55-61.

Eastman, N. (1997) The Mental Health (Patients in the Community) Act 1995. A clinical analysis. British Journal of Psychiatry, 170, 492-496.

Geddes, J. R., Juszcak, E., O'Brien, F., et al (1997) Suicide in the 12 months after discharge from psychiatric inpatient care, Scotland 1968-92. Journal of Epidemiology and Community Health, 51, 430-434.

Glover, G. R., Leese, M. \& McCrone, P. (1999) More severe mental illness is more concentrated in deprived areas. British Journal of Psychiatry, 175, 544-548.

Goldstein, J. M. \& Simpson, J. C. (1995) Validity: definitions and applications to psychiatric research. In Textbook in Psychiatric Epidemiology (eds M. T. Tsuang, M. Tohen \& G. E. P. Zahner), pp. 233-236. New York: Wiley-Liss.

Gunn, J. (1977) Management of the mentally abnormal offender: integrated or parallel. Proceedings of the Royal Society of Medicine, 70, 887-890.

— \& Robertson, G. (1976) Drawing a criminal profile. British Journal of Criminology, 16, 156-160.

Hinton, R. (1998) The physical environment. In Managing High Security Psychiatric Care (eds C. Kaye \& A. Franey) London: Jessica Kingsley

Home Office \& Department of Health and Social Services (1975) Report of the Committee on Mentally Abnormal Offenders (Butler Report). London: HMSO.

James, D. V. (1999) Court diversion at 10 years: can it work, does it work and has it a future? Journal of Forensic Psychiatry, 10, 507-524.

-, Finberg, N. A., Shah, A. K., et al (1990) An increase in violence on an acute psychiatric ward. A study of associated factors. British Journal of Psychiatry, 156, 846-852.

Jamieson, E., Butwell, M., Taylor, P., et al (2000) Trends in special (high-security) hospitals. 1: Referrals and admissions. British Journal of Psychiatry, 176, 253-259.

Johnson, S., Ramsey, R., Thornicroft, G., et al (1997) London's Mental Health: The Report to the King's Fund London Commission. London: King's Fund.

Kennedy, H. (2001) Risk assessment is inseparable from risk management. Comment on Szmuckler. Psychiatric Bulletin 25, 208-211.

—, Iveson, R. C. \& Hill, O. (1999) Violence, homicide and suicide: strong correlation and wide variation across districts. British Journal of Psychiatry, 175, 462-466.

Kinsley, J. (1998) Security and therapy. In Managing High Security Psychiatric Care (eds C. Kaye \& A. Franey). London: Jessica Kingsley.

Monahan, J. (1993) Limiting therapist exposure to Tarasoff liability: guidelines for risk containment. American 
Psychologist, 48, 242-250.

National Health Service Estates (1999) Design Guide: Medium Secure Psychiatric Units. Leeds: NHS Estates.

O'Grady, J. (1990) The complementary role of regional and local secure provision for psychiatric patients. Health Trends, 22, 14-16.

Pierzchniak, P., Purchase, N. \& Kennedy, H. G. (1997) Liaison between court, prison and psychiatric services. Health Trends, 29, 26-29.

- Farnham, F., DeTaranto, N., et al (1999) Assessing the needs of patients in secure settings: a multidisciplinary approach. Journal of Forensic Psychiatry, 23, 343-354.

Powell, F. (1998) Freedom from restraint. In Managing High Security Psychiatric Care (eds C. Kaye \& A. Franey). London: Jessica Kingsley.

Purchase, N. D., McCallum, A. K. \& Kennedy, H. G. (1996) Evaluation of a psychiatric court liaison scheme in north London. BMJ, 313, 531-532.

Reason, J. (2000) Human error: models and management. $B M J, 320,768-770$.

Reed, J. (1992) Review of Health and Social Services for Mentally Disordered Offenders and Others Requiring Similar Services: Final Summary Report (Cm 2088). London: Stationery Office.

Royal College of Psychiatrists (1975) 'Norms' for medical staffing of a forensic psychiatry service within the National Health Service in England and Wales. British Journal of Psychiatry News and Notes, June, pp. 5-10.

-(1995) Strategies for the Management of Disturbed and Violent Patients in Psychiatric Units (Council Report CR41) London: Royal College of Psychiatrists.

- (1998) 'Not Just Bricks and Mortar': Report of the Royal College of Psychiatrists Working Group on the Size, Staffing, Structure, Siting and Security of New Acute Adult Psychiatric In-patient Units (Council Report CR62). London: Royal College of Psychiatrists.

- (2000) Good Medical Practice in the Psychiatric Care of Potentially Violent Patients in the Community (Council Report, CR80). London: Royal College of Psychiatrists.

Scott, P. D. (1977) Assessing dangerousness in criminals British Journal of Psychiatry, 131, 127-142.

Shaw, J., McKenna, J., Snowden, P., et al (1994) Clinical features and placement needs of all North West Region patients currently in Special Hospital. Journal of Forensic Psychiatry, 5, 93-106.

Shrout, P. E. (1995) Reliability. In Textbook in Psychiatric Epidemiology (eds M. T. Tsuang, M. Tohen \& G. E. P. Zahner), pp. 213-227. New York: Wiley-Liss.

Snowden, P., McKenna, J. \& Jasper, A. (1999) Management of conditionally discharged patients and others who present similar risks in the community: integrated or parallel? Journal of Forensic Psychiatry, 10, 583-596.

Steadman, H. J., Mulvey, E., Monahan, J., et al (1998) Violence by people discharged from acute psychiatric inpatient facilities and by others in the same neighbourhoods. Archives of General Psychiatry, 55, 393-401.

Szmukler, G. (2000) Homicide inquiries: What sense do they make? Psychiatric Bulletin, 24, 6-10.

Tilt, R. (2000) Report of the Review of Security at the High Security Hospitals. London: Department of Health.

Wilson, J. Q. \& Kelling, G. (1982) Broken windows. Atlantic Monthly, March, 29-38.

$R$ v. Mental Health Review Tribunal and Others ex parte Hall [1999] 4 AllER 883.

\section{Multiple choice questions}

1. Relational security is:

a the ratio of staff to patients

$\mathrm{b}$ the quality of rapport between staff and patients

c the risk of violence in the family

d impaired by reduced continuity of care

e less important than environmental or procedural security.

2. Environmental security includes:

a the level of physical and design impediments to absconding

b design features that enable good observation

c regular maintenance and decoration

d inspection by the Mental Health Act Commission

e the most restrictive environment possible.

3. Medium-term security:

a is usually organised for populations of 1.53.5 million.

b has lower relational security levels than high secure hospitals

c generally discharges patients within 18 months

d staff usually provide other community services

e can best be described by patient characteristics, not security properties.

4. Therapeutic security:

a is an oxymoron

$\mathrm{b}$ includes the environmental, relational and procedural characteristics of any service

c level should depend on risk assessment

d can result in excessive lengths of stay because of lack of access to appropriate placements

e includes mapping the services for a region as an essential part of risk management.

5. Thresholds for admission and transfer between levels of security:

a vary between regions because of resources

b combine quantitative and qualitative judgements

c need not be described in reviewable terms

$\mathrm{d}$ are not influenced by issues of public confidence

e should be audited and compared with benchmarks at intervals.

\section{MCQ answers}

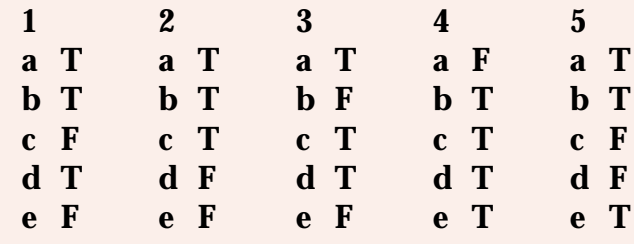

